\title{
The effect of quercetin on microRNA expression: A critical review
}

\author{
Zdenek Dostala ${ }^{\mathrm{a}, \mathrm{b}}$, Martin Modriansky ${ }^{\mathrm{a}, \mathrm{b}}$
}

Quercetin, a flavonoid with multiple proven health benefits to both man and animals, displays a plethora of biological activities, collectively referred to as pleiotropic. The most studied of these are antioxidant and anti-inflammatory but modulation of signalling pathways is important as well. One of the lesser-known and recently discovered roles of quercetin, is modulation of microRNA (miRNA) expression. miRNAs are important posttranscriptional modulators that play a critical role in health and disease and many of these non-coding oligonucleotides are recognized as oncogenic or tumor suppressor miRNAs. This review is an evaluation of the recent relevant literature on the subject, with focus on the ability of quercetin to modulate miRNA expression. It includes a summary of recent knowledge on miRNAs deregulated by quercetin, an overview of quercetin pharmacokinetics and miRNA biogenesis, for the interested reader.

Key words: polyphenols, microRNA, biogenesis, expression

Received: February 27, 2019; Accepted with revision: June 11, 2019; Available online: June 25, 2019

https://doi.org/10.5507/bp.2019.030

${ }^{a}$ Department of Medical Chemistry and Biochemistry, Faculty of Medicine and Dentistry, Palacký University, Olomouc, Czech Republic 'Institute of Molecular and Translational Medicine, Faculty of Medicine and Dentistry, Palacký University, Olomouc, Czech Republic Corresponding author: Martin Modriansky, e-mail:martin.modriansky@upol.cz

\section{INTRODUCTION}

Quercetin, a biologically active compound, is a member of an extensive group of natural compounds called polyphenols. These are ubiquitous in the human diet and an average person can consume more than $1 \mathrm{~g}$ per day $^{1,2}$. The primary role of polyphenols in plants is defense against environmental stress such as UV-irradiation and predators. They also affect growth (development regulators), mediate pigmentation and attract pollinators ${ }^{3,4}$. Polyphenols are classified as flavonoids, lignans, stilbenes, phenolic acids, coumarins, hydroxycinnamic acids and others ${ }^{3}$. They display a number of biological activities such as radical scavenging, antioxidant and antiinflammatory properties as mentioned ${ }^{5}$. They can also modulate cell signalling cascades ${ }^{6,7}$. Some cellular signals are transmitted and amplified via kinases, some of which can be inhibited by quercetin and other polyphenols ${ }^{7-9}$.

Quercetin, whose chemical structure is shown in Fig. 1, is one of the most abundant flavonoids, belonging to the flavonol subgroup ${ }^{10}$. Its protective effects are mediated by multifaceted, pleiotropic action.<smiles>O=c1c(O)c(-c2cc(O)c(O)c(O)c2)oc2cc(O)cc(O)c12</smiles>

Fig. 1. Chemical structure of quercetin.
Quercetin is found abundantly in various foods such as fruits (apple and black currant), vegetables (onion and green beans), beverages (tea) and spices ${ }^{11,12}$. It exists in two forms: an aglycone or a glycosylated form. The sugar moiety, glucose, other monosaccharides or disaccharides e.g. rhamnose or rutinose, is connected to different carbons of the structure via $O$-glycosidic linkage. The C-3 carbon is the most common position but the glycosylation may appear on carbons 4' and 7 (ref. $\left.{ }^{13}\right)$. 4'-O-glucoside is considered the major representative of quercetin glycosides in onion ${ }^{14}$ but C-glycosides have also been described as well ${ }^{15}$. From a dietary point of view, mostly quercetin glycosides are found in food with a negligible portion of the aglycone ${ }^{16,17}$, although some authors have suggested that the aglycone form may be present in significant quantities in some red wines ${ }^{18}$. Chemically, quercetin is a bright yellow crystallic substance with very good solubility either in DMSO (150 g/L, RT) (ref. ${ }^{19}$ ), inferior in $50 \%$ ethanol $\left(4.02 \mathrm{~g} / \mathrm{L}, 37^{\circ} \mathrm{C}\right)\left(\right.$ ref. $\left.^{20}\right)$ and practically insoluble in water $\left(4.7 / 10.28 \mathrm{mg} / \mathrm{L}, 37^{\circ} \mathrm{C}\right.$, based on solubility in PBS) $\left(\right.$ ref. $\left.^{20,21}\right)$.

\section{Pharmacokinetics of quercetin}

The bioavailability of quercetin in a single oral dose is fairly low ( $\leq 1 \%$ of unchanged compound) (ref. ${ }^{22}$ ). In the high doses used by Gugler et al. ${ }^{22}$ ( $4 \mathrm{~g}$ ), quercetin solubility is probably the main limitation as more than $50 \%$ of unchanged quercetin was found in the feces. Absorption of quercetin takes place mainly in the intestine ${ }^{23}$ but also in the epithelium of the oral cavity ${ }^{17}$. Older literature suggested that quercetin glucosides are not absorbed at all and absorption occurs with aglycone alone ${ }^{24}$. It has since been suggested that hydrolysis of the glucosides is mediated by oral and gut microflora ${ }^{17,25}$. On the other hand, 
intestinal microflora and chemical reactions can cause quercetin degradation. In 2001, Walle et al. ${ }^{26}$ published data obtained with radiolabeled quercetin and showed that quercetin is metabolized in the human body with $\mathrm{CO}_{2}$ generation as the end product (mean value $52.1 / 43.2 \%$ of administrated dose; oral/intravenous application) (ref. ${ }^{26}$ ). This study has the limitation of using only one radiolabeled carbon that restricts tracking of other products. Similar results were published with data obtained using a rat model where $\mathrm{CO}_{2}$ generation was also observed ${ }^{27}$. The degradation of flavonoids by intestinal microflora was found in both in vitro and in vivo and it is usually linked with ring-fission products ${ }^{25,28}$.

Other documented possibilities of quercetin glucoside hydrolysis are enterocyte or liver cytosolic $\beta$-glucosidase, whose activities depend on the sugar moiety and its position, and lactase phloridzin hydrolase (LPH) enzymes ${ }^{16,29}$. LPH could be important in absorption of quercetin due to its localization: it resides on the luminal side of the brush border ${ }^{29}$. The effect of cytosolic broad specificity $\beta$-glucosidase in enterocytes and hepatocytes is questionable because the quercetin glucosides would be transported into the cell before the hydrolytic cleavage occurs in the intestine. On the other hand, some publications describe the uptake of a small amount of flavonol glucosides into the circulation ${ }^{30}$. Hollman et al. ${ }^{31}$ showed that quercetin glucosides are better absorbed than the aglycone in ileostomy patients but these authors used only indirect calculation. In fact all samples were subjected to hydrolysis which means that there is lack of information on the aglycone:glucoside ratio in ileostomy fluid or other tested samples (see Walle et al. ${ }^{32}$ ). Also, quercetin and its glycosides were evaluated for stability during a two/four/3.25 h long incubation period with gastric fluid/ duodenal fluid/ileostomy effluent, respectively. The results indicated high stability of tested compounds but it appears that at least free quercetin tested during the study exceeded its expected solubility in aqueous solution. The study also showed only small hydrolysis of rutin and this corresponds to previously published results ${ }^{16,29}$.

Quercetin is metabolized by different phase I and II enzymes after absorption. Products are predominantly quercetin glucuronides and sulfates that are generated within hepatocytes and enterocytes ${ }^{3,33,34}$. Other products of quercetin metabolism include methylated querce$\operatorname{tin}^{3,34}$. While in the intestine, bacterial cleavage of the hydrophilic moiety can produce aglycone, i.e. cause deconjugation, from quercetin metabolites, which could be re-absorbed ${ }^{3,35}$. The products of quercetin metabolism are excreted into urine and feces as well as being exhaled ${ }^{3}$.

Quercetin is capable of inhibiting some cytochromes P450 in vitro ${ }^{36}$, and this may affect the metabolism of quercetin itself or other drugs. Moreover, a decrease in CYP1A1 and CYP1B1 mRNA was observed in noncancerous colon cells after treatment with flavonol-rich fraction from yaupon holly containing quercetin-3-rutinoside $^{37}$. However, contradictory information is available for isoquercitrin, a quercetin glucoside. Three selected members of the P450 family showed an enhancement of liver P450 activity after isoquercitrin gastric gavage in rats ${ }^{38}$.
Increasing the bioavailability of quercetin is another aim of current research. From results published by Gugler et al. ${ }^{22}$, we can conclude that a higher single dose of quercetin does not improve absorption for several reasons, the most important being solubility in water. It is wellknown that the solubility of quercetin in water is poor and hence the goal is to improve aqueous solubility (see below). It is also necessary to facilitate transport across membranes. An interesting approach is enclosing quercetin into special micelles ${ }^{39}$ or mixing it with various lipids to create quercetin containing liposomes ${ }^{20}$. Another idea is to overcome low bioavailability by using multiple doses of quercetin repeatedly ${ }^{40}$. The idea was tested on a human model and a plasma quercetin concentration of $1.5 \mu \mathrm{M}$ was achieved in the test subject when $1 \mathrm{~g}$ per day was applied for 28 days. This study has a limitation due the pre-analytic sample preparation, which included a hydrolysis step that discarded all information about quercetin metabolites formed by second phase enzymes such as amount of glucuronides, sulfates etc. ( ref. $^{40}$ ). The conclusion is that the "long" elimination time is connected with bioaccumulation of quercetin.

\section{miRNA}

miRNAs are defined as short non-coding single strands of RNA with approximately 18-25 bases. The first mention of these molecules appeared in 1993. Scientists from Harvard College found a small RNA product of the lin-4 gene that is able to control the lin-14 protein level in Caenorhabditis elegans ${ }^{41}$. These molecules provide a modality for posttranscriptional modulation of gene expression in this organism. miRNAs have several valid targets, sometimes dozens of targets, and some miRNAs can even share their targets ${ }^{42}$. As of the writing of this article, 1917 human miRNA precursors have been described in miRBase 22 (http://www.mirbase.org/).

\section{miRNA biogenesis}

The first step in canonical miRNA biogenesis is RNA polymerase II catalyzed transcription of their genes from DNA (ref. ${ }^{43}$ ). This reaction generates long primary transcripts typically containing over a thousand nucleotides (pri-miRNA). The process continues by cropping the primiRNA to the size of up to hundred nucleotides long products called precursor miRNA (pre-miRNA). The editing is mediated by a microprocessor complex that contains two major components Drosha (belongs to the RNAse III family) and DGCR8 (also called DiGeorge Syndrome Critical Region 8) (ref. ${ }^{44,45}$ ). The next step is the shuttling of pre-miRNAs to the cytosol. This occurs in the presence of exportin-5 and RanGTP (ref. ${ }^{46,47}$ ). Dicer (RNAse III enzyme) accesses the pre-miRNAs and digests it to mature, 18 - 25 nucleotide long double stranded products $^{48,49}$. Unwinding of miRNA duplexes initiates the N-domain of argonaute 2 during RISC (RNA inducing silencing complex) assembly ${ }^{50}$ while attracting other important proteins such as Dicer, TRBP (ref. ${ }^{51}$ ). Within the complex formation, a guide strand is incorporated into the complex (strand with less stable pairing at the 5 'end), whereas a passenger strand is degraded ${ }^{52}$. The ac- 
tive RIS complex both reduces stability and cleaves the target mRNA, which is the case of full complementarity of miRNA against target mRNA. Partial complementarity of miRNA blocks mRNA for ribosomal translation but it does not cleave a target mRNA immediately ${ }^{53}$. Moreover, mRNA/RISC complexes are probably stored and also degraded in p-bodies. For more detailed information about p-bodies see a review by Parker et al. ${ }^{54}$. The canonical miRNA biogenesis pathway is summarized in Fig. 2 .

miRNAs are interesting and important molecules in cell processes because a single miRNA has the ability

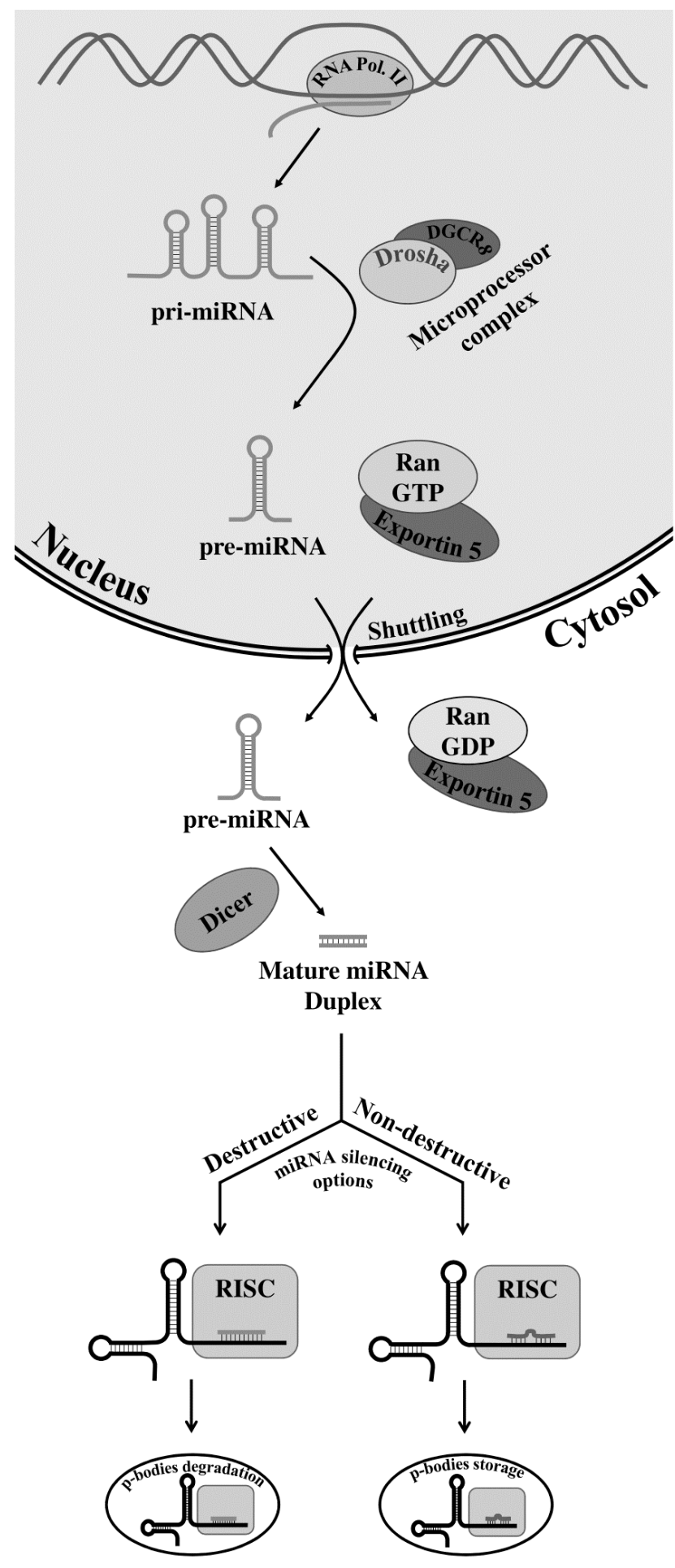

Fig. 2. Biogenesis of miRNA (basic scheme). to modulate gene expression of multiple targets, thereby changing the cell phenotype. There are a number of deregulated miRNAs in different types of diseases. They are therefore being extensively studied especially in relation to cancer and their level may be associated with specific types of tumor. Ouzang et al. ${ }^{55}$ for example identified a group of up- and down-regulated miRNAs compared to normal tissue expression. Experiments based on restoration of normal non-pathologic expression of selected miRNA or even exceeding it showed elevated sensitivity of tested cancer cells to conventional treatment ${ }^{56}$. Modulation of miRNA expression could be used in the future against a number of diseases.

\section{miRNAs modulated by quercetin}

\section{miR-146a}

Tao et al. ${ }^{57}$ found that quercetin increased the expression of miR-146a in human breast cancer cells ${ }^{57}$. Generally, miR-146a is known as a posttranscriptional modulator of several important genes. For example, its validated targets are BRCA1, BRCA2 (ref. ${ }^{58}$ ) involved in repairing double strand breaks in DNA or the EGFR receptor ${ }^{59}$, a transmembrane tyrosine kinase connected with pro-survival signalling. Overexpressed EGFR is often found in tumors and linked to aggressive behavior in cancer cells. This study found significant upregulation of miR-146a, approximately four- to five-fold of control for MCF-7/MDA-MB-231 cells, caused by the highest quercetin concentration tested during $48 \mathrm{~h}$ treatment. The result was a reduction in cell survival to below $40 \%$. The observed effect was linked to negatively affected expression of EGFR, increase in Bax protein level and downstream activation of caspase- 3 during $24 \mathrm{~h}$ treatment. In addition, the authors used miR-146a/anti-miR-146a transfection for validation of the observed effects. Moreover, a mouse xenograft model was used during the study. These experiments showed decrease in cancer volume and an increase in expression of miR-146a, almost two-fold higher than control, after quercetin treatment ( $10 \mathrm{mg} / \mathrm{kg}$ for 8 weeks). Unfortunately, the authors did not describe the method of application of quercetin ${ }^{57}$. The article contains discrepancies between text and images and authors used a non-standard unit for the concentrations of the tested compound (see Table 1). The literature suggests conflicting effects of miR-146a in cancer cell line MCF-7. For example, Gao et al. ${ }^{60}$ discusses the impact of the miR-146a-5p overexpression on enhanced proliferation in this cell line ${ }^{60}$. Overall, these results suggest another contribution of quercetin that cooperates with miR-146a up-regulation.

An article published by Tao et al. ${ }^{57}$ is not the only article showing that miR-146a is modulated by quercetin. Noratto et al. ${ }^{37}$ examined fractions from yaupon holly leaf extract. The flavonol-rich fraction turned out to be effective. Quercetin-3-rutinoside and kaempferol-3-rutinoside were determined as major flavonol compounds of this fraction by HPLC/MS ( $\left.\mathrm{MS}^{2}, \mathrm{MS}^{3}\right)$ and were characterized as gallic acid equivalents (GAE). The experiments were performed with CCD-18Co cells (normal colon cells), in which LPS treatment down-regulated miR-146a 
expression. Combined treatment of LPS with the highest concentration of $40 \mathrm{mg} \mathrm{GAE} / \mathrm{L}$ resulted in the return of miR-146a expression to the level of control. Further experiments yielded interesting data because the relative expression of miR-146a exceeded the level in control (nontreated) cells after combination of the extract fraction (20 mg GAE/L) with miR-146a inhibitor as well as combination of the flavonol rich extract + LPS + miR-146a inhibitor. The authors suggested that miR-146a contributes to the anti-inflammatory properties of the tested fraction due to the regulation of its targets IRAK-1 and TRAF-6 (ref. ${ }^{37}$ ). IRAK-1 and TRAF-6, a part of the TLR pathway, were validated as miR-146a targets elsewhere ${ }^{61}$.

\section{miR-27a}

Another example of combined study is Del Follo Martinez et al. ${ }^{62}$ who used a quercetin:resveratrol mixture in a 1:1 ratio. The researchers used the HT-29 cell line as a model of colon cancer and tested the mixture for its potential anticancer properties. A decrease in miR-27a was found. This miRNA is discussed as oncogenic because it is linked to regulation of ZBTB10, a zinc finger protein. The main effect of ZBTB10 is probably mediated via repression of $\mathrm{Sp}$ transcription factors. These are a part of the transcription factor family that regulates several housekeeping genes related to initiation of cancer and its progression. miR-27a was downregulated two-fold after the treatment that resulted in upregulation of ZBTB10. The impact was partially demonstrated using miR-27a mimics. On the other hand, modulation of miR-27a by the mixture did not respond in a dose dependent manner whereas ZBTB10 mRNA did. The data suggest another effect of this mixture ${ }^{62}$.

miR-27a was downregulated in the same way by another combination of polyphenols, namely quercetin and hyperoside (quercetin-3-O-galactoside), also in a 1:1 ratio. 786-O renal cancer cells were used as the model for these experiments. It is remarkable that almost all the figures, results, experimental design and even text bear a strong resemblance to those presented in Del Follo Martinez et al. ${ }^{62}$ with few exceptions. Many results were surprisingly similar, with $\mathrm{IC}_{50}$ differences smaller than $0.1 \mu \mathrm{g} / \mathrm{mL}$ between the articles ${ }^{63}$. It is possible to speculate from the similarities that quercetin is responsible for the effect and the other compound plays a spectator role.

\section{miR-21}

The same research group published another paper in 2015 describing the effect of the same combination quercetin:hyperoside (1:1 ratio) in a different cell model - prostate cancer cells PC3 cell line. The results show deregulation of miR-21, a well-known oncogenic miRNA, caused by quercetin/hyperoside combination. The miR-21 was downregulated compared to control cells by as much as 4.3-fold at the highest concentration, and the deregulation was accompanied by upregulation of PDCD4, a tumor suppressor. The influence of miR-21 was validated via pre-miR-21 transfection ${ }^{64}$. Because hyperoside is a quercetin glycoside, its combination with quercetin aglycon suggests that the synergistic effect may be linked to a simple increase in free quercetin via deglycosylation. The same could actually apply to miR-27 as discussed in the previous paragraph.

Wang and colleagues ${ }^{65}$ used on a quercetin combination as well, in this case a mix of quercetin and arctigenin evaluated in prostate cancer cell models (LAPC-4 and LNCaP cell lines). They compared miRNA expression of control cells with those treated with the arctigenin/quercetin combination and uncovered several miRNAs that were downregulated. Both cell lines showed a decrease of at least $20 \%$ relative to negative control in miR-21, miR$19 \mathrm{~b}$ and miR-148a expression. However, LAPC cells were more sensitive to the treatment (Table 1). Moreover, the LAPC-4 cell line treated by arctigenin showed almost the same expression of miR-19b and miR-21 even displayed a decreasing trend compared to arctigenin/quercetin samples. However, quercetin monotherapy was usually weaker and, surprisingly, quercetin displayed an opposite behavior for miR-21 in both cell lines ${ }^{65}$. MiR-19b and miR-21 are usually designated as oncogenic ${ }^{66}$ and their downregulation is recognized as a positive effect. The last positive information in the paper is that no type of treatment had any effect on proliferation of normal prostate epithelial cells (PrEC) $\left(\right.$ ref. $\left.{ }^{65}\right)$.

Quercetin monotherapy modulates miR-21 as published by an Iranian group of scientists, who tested the effects of quercetin on breast cancer cell line MCF-7. The proliferation of the cell line was strongly affected only at very high concentrations ( 50 and $100 \mu \mathrm{M}$ quercetin) after $24 \mathrm{~h}$ treatment. However, the paper presents two conflicting $\mathrm{IC}_{50}$ values: the data from Fig. 1 do not correspond with the $7.06 \mu \mathrm{M}$ value presented in the text. Nevertheless, relative expression of miR-21 was significantly downregulated by quercetin, approximately two-fold at a concentration of $10 \mu \mathrm{M}$. The authors performed RT-PCR analysis of gene expression of PTEN and Maspin, targets of miR-21 and showed that both mRNA were upregulated ${ }^{67}$.

Expression of miR-21 responds to the rate of oxidative stress, e.g. as result of environmental pollutant exposure. $\mathrm{Cr}^{\mathrm{VI}+}$ ions, inducers of ROS formation, are designated as carcinogenic and are connected with lung cancer. The study evaluated quercetin for its effects on acute $\mathrm{Cr}^{\mathrm{VI}+}$ response and alleviation of $\mathrm{Cr}^{\mathrm{VI}+}$ induced malignant transformation. During the study it was discovered that quercetin regulates the transformation through miR-21 and its target protein PDCD4. Three sets of experiments were performed (in vitro and in vivo). The first set was done on BEAS-2B cells, which are lung epithelial cells. miR-21 was upregulated four-fold by $\mathrm{Cr}^{\mathrm{VI}+}$ ions, compared to untreated control (3.4/6.0/18 for chronic exposure - 2/4/6 months, respectively). The upregulation was reduced by quercetin approximately three-fold compared to $\mathrm{Cr}^{\mathrm{VI}+}$ treated cells in acute $\mathrm{Cr}^{\mathrm{VI}+}$ exposure and $2.1 / 2.5 / 4.3$ fold (roughly) in chronic $\mathrm{Cr}^{\mathrm{VI}+}$ exposure (2/4/6 months). The chronic $\mathrm{Cr}^{\mathrm{VI}+}$ treatment with quercetin resulted in modulation of colony number. It is promising that the chronic effect of $\mathrm{Cr}^{\mathrm{VI}+}$ was reversible by quercetin at a relatively low concentration. The second series of experiments included an athymic nude mouse xenograft model with injected chromium transformed cells. When the tumor reached 
a given volume, the quercetin treatment began and took 30 days $(10 \mathrm{mg} / \mathrm{kg} /$ day, intraperitoneally). miR-21 was downregulated in the tumor cells as well, confirming the positive effect of quercetin in vivo. The third approach consisted of a mouse xenograft model with application of pre-treated BEAS-2B cells. The pre-treatment of the cells was identical to that described in the chronic experiment. Tumor analysis was done 30 days later. Quercetin pre-treated BEAS-2B produced smaller tumors with lower expression of miR-21 ( ref. $^{68}$ ).

Finally, a Chinese research group form Daqingshi No. 4 Hospital published an article describing attenuation of fibrosis induced by transforming growth factor- $\beta$ (TGF- $\beta$ ) in HK-2 cell line (renal tubular epithelial cells) as a result of quercetin treatment $(15 \mathrm{mg} / \mathrm{mL})$ in 2018 . The effect is associated with suppression of miR-21-5p overexpression caused by TGF- $\beta$ treatment. The effects of quercetin are partially reversed by miR-21 mimics. On the other hand, the doses of quercetin used were extremely high and unachievable in aqueous medium. It seems that the concentrations reported correspond to stock solutions, not the final concentrations in the medium. In addition, important information is missing in the paper, e.g. duration of incubation during selected experiments ${ }^{69}$.

\section{miR-155}

Quercetin causes changes in levels of miR-155 (ref. ${ }^{70}$ ) that are induced by the inflammation signalling pathway but react in the opposite way compared to the effect on miR-146a. The study assessed modulation of the miRNA by quercetin and its two important metabolites in murine RAW264.7 macrophages. Normally, miR-155 is increased 12 -fold by LPS treatment, relative to negative control. However, the presence of quercetin or its metabolite isorhamnetin reduced the effect of LPS by approximately 1.8/1.5 fold. The assumed mechanism of miR-155 regulation by quercetin is via direct and indirect modulation through NFkB. Quercetin-3-glucuronide, that was also used in the study, had no impact ${ }^{70}$.

\section{let-7 family}

The influence of quercetin on let-7a in pancreatic ductal adenocarcinoma was shown by Appari et al. ${ }^{71}$. These authors demonstrated that quercetin treatment for $72 \mathrm{~h}$ increased the amount of let-7a 2.45/1.6/1.45 fold in MIAPaCa2/BxPC-3/PacaDD-183 cells compared to control, 3.0/2.3/2.45 fold in MIA-PaCa2/BxPC-3/PacaDD-183 cells in combination treatment with sulforaphane and 3.2/3.1/3.1 fold in MIA-PaCa2/BxPC-3/PacaDD-183 cells with green tea catechins, respectively. let-7a enhancement was accompanied by K-Ras downregulation on both mRNA and protein levels with the exception of quercetin only treated cells, in which no changes in K-Ras protein levels were observed ${ }^{71}$. The effect of let-7a against Ras protein correlates with the findings of Johnson et al. ${ }^{72}$. Non-malignant pancreatic ductal cells showed minimal changes ${ }^{71}$.

Similar data for let-7 family, 7c isoform in particular, in pancreatic ductal adenocarcinoma were published by Nwaeburu et al. ${ }^{73}$. The miRNA showed approximately
1.8/1.3/1.9 fold higher expression after $50 \mu \mathrm{M}$ quercetin treatment in AsPC-1/AsanPACA/PANC-1 cells. A result of let-7c modulation in AsPC-1 was positive regulation of Numb protein, inhibitor of Notch, accompanied by a decrease in Notch protein level. The authors also confirmed an additional five miRNAs with response to quercetin via RT-PCR (miR-200a/200b/103/125b/1202) and published a heatmap of 24 miRNAs with the highest deregulation after quercetin treatment ${ }^{73}$.

\section{miR-200b-3p}

A follow-up study by Nwaeburu et al. ${ }^{74}$ focused on miR-200b-3p that was significantly modulated (upregulated more than 2.5 times) by quercetin $(50 \mu \mathrm{M})$ in pancreatic ductal adenocarcinoma (AsPC-1). Activity of miR-200b-3p against Notch 3' UTR region was demonstrated. The article describes an unusual combination of effects. miR-200b caused attenuation of luciferase activity of reporter gene containing 3' UTR of Notch1, but there was no effect on Notch1 mRNA expression. This suggests that miR-200b-3p only blocks translation and does not cause cleavage of mRNA. The inhibition of Notch protein is associated with cell fate decision therefore the quercetin treated cells prefer an asymmetric cell division. On the other hand, the results of miR-200b-3p transfection showed activation of Numb transcription ${ }^{74}$ similar to let-7c transfection in Nwaeburu et al. ${ }^{73}$ published in 2016. It seems that miR-200b-3p associated activation of Numb is more important than 3' UTR anti-notch activity. If we consider both articles published by Nwaeburu et al. ${ }^{73,74}$, we can recognize a synergy in the effect of the two miRNAs, miR-200b-3p and let-7c, on quercetin treated PDA cells. Both miR-200b-3p, and let-7c, upregulate Numb protein, the Notch 1 inhibitor.

\section{miR-17-3p}

Quercetin also affects expression of ferroportin, a membrane exporter of ferrous iron in the intestine, via miR-17-3p. The exporter is located in enterocytes, more precisely on the basolateral membrane ${ }^{75}$. The main role of the protein is to transport iron from intracellular to extracellular space. A specific block of enterocyte ferroportin expression should have an influence on intestinal iron absorption ${ }^{76}$. The research group used Caco- 2 TC7 cell line as their cell model for miRNAs experiments. During miRNA array analysis, some miRNAs were identified with an increase in expression of over 1.5 fold after $10 \mu \mathrm{M}$ quercetin treatment, 33 miRNAs in total according to the text, with another two in the supplementary table. Ferroportin 3'UTR region contains binding site for miR-17-3p. The PCR data showed that miR-17-3p is upregulated over 90 (a.u.) compared to control. Moreover, quercetin decreases activity of luciferase plasmid containing the ferroportin 3' UTR region ${ }^{75}$. The article also reports that quercetin and its 4-O-methyl analog increase uptake and decrease efflux of iron in rat duodenum.

\section{miR-16}

Sonoki and colleagues focused on the impact of quercetin treatment in lung adenocarcinoma A549 cells. The 
A549 cells were exposed to $50 \mu \mathrm{M}$ quercetin for $24 \mathrm{~h}$ and observed induction of miR-16 expression, approximately 1.4 fold compared to untreated control. The result was a decrease in Claudin-2 mRNA and protein level, with the effect being partially reversed by miR-16 inhibitor ${ }^{77}$.

\section{miR-217}

Zhang et al. ${ }^{78}$ tested the effect of quercetin on cisplatin treatment in an osteosarcoma model. They used the 143B cell line and recognized that miR-217 is partially responsible for quercetin- mediated sensitivity of cells to cisplatin. The induced expression of miR-217 caused a decrease of K-Ras protein and mRNA expression as both quercetin and cisplatin upregulate miR-217 expression with a synergic effect if used together. The importance of miR-217 was shown via miR-217 mimics/anti-miR-217 that partially enhance/reverse cisplatin and/or quercetin outcome. The paper also includes the information that $\mathrm{K}-\mathrm{R}$ as regulates the PI3K/AKT pathway ${ }^{78}$. K-Ras is not the only player in PI3K/AKT regulation in the treatment, since quercetin is also a known regulator of the pathway.

\section{miR-142-3p}

miR-142-3p is another miRNA modulated by quercetin. MacKenzie et al. ${ }^{79}$ discovered that quercetin at 100 $\mu \mathrm{M}$ (as well as triptolide at $100 \mathrm{nM}$ ) upregulated the miRNA in three different types of pancreatic ductal adenocarcinoma cells: over three-fold in MIA PaCa-2 cells, almost eight-fold in Capan-1 cells and more than threefold in S2-013 cells. Most of the experiments however were performed only with triptolide ${ }^{79}$.

\section{miR-145}

Dose dependent induction of miR-145 was observed in ovarian cancer cells (SKOV-3 and A2780) as a result of quercetin treatment $(0-100 \mu \mathrm{m} / \mathrm{mL})$. miR-145 was increased approximately 3/3.5 fold for SKOV-3/A2780 at the highest concentration after $24 \mathrm{~h}$ treatment. Quercetin $(50 \mu \mathrm{m} / \mathrm{mL})$ was indicated as $\mathrm{IC}_{50}$ for $48 \mathrm{~h}$ incubation and this concentration was used in further experiments. The miRNA upregulation is linked to growth inhibition and enhancement of caspase- 3 cleavage that can be reversed by miRNA-inhibitor. However, the article does not reveal the molecular mechanism in detail such as which target protein is modulated by upregulated miR-145. We assume that the observed caspase effect is a consequence of miR-145 protein target regulation ${ }^{80}$. The article provides concentrations in " $\mu \mathrm{m} / \mathrm{mL}$, however it is not clear what this non-standard unit represents (see also in Tao et al. ${ }^{57}$ ).

\section{In vivo experiments (several miRNAs tested)}

In vitro experiments aside, some in vivo studies into quercetin's effect on miRNA were performed. An example is the study by Wien et al. ${ }^{81}$, in which male Wistar rats were fed a diet containing approximately $10 \mathrm{mg} / \mathrm{kg}$ per day quercetin for 7 weeks. PCR array analysis of $352 \mathrm{miR}$ NA showed 23 deregulated hepatic miRNAs. Nineteen of them had more than three-fold lower expression than control group, although the published table in the article contains only 13 miRNAs. The remaining miRNAs (four species) showed increased expression by the same value (see Table 2). The group demonstrated that the most deregulated rno-miR-125b-3p (nine fold) presumably induces $\gamma$-glutamyl hydrolase expression (measured at mRNA level by RT-PCR) due to its downregulation ${ }^{81}$. The authors used a sample pooled from eight animals for each group tested, to evaluate miRNA expression via PCR array. $\gamma$-glutamyl hydrolase represents an important enzyme associated with cancer and its high levels are discussed as a poor prognosis marker during invasive breast cancer ${ }^{82}$. Rats are not the only model used, as there are also at least five articles using mice as an in vivo model (see Table 2).

Quercetin and 8 other polyphenols were investigated in apoE deficient mice, a model of deregulated lipid metabolism. The study used microarrays for miRNA (567 species) and mRNA (35,852 probes) expression patterns (signatures) as a powerful tool of comprehensive analysis. The experiment was designed as follows - two week's exposure with $0.006 \%(\mathrm{w} / \mathrm{w})$ of quercetin in the diet. The dose corresponds to $30 \mathrm{mg}$ per day for humans. The results showed 47 miRNAs with different expression for quercetin and control group. 22 miRNAs had reduced expression and $25 \mathrm{miRNAs}$ had induced expression. Moreover, five miRNAs displayed expression similarities across tested polyphenols. Three species exhibited lower expression (mmu-miR-30c-1*, mmu-miR-374* and mmu-miR-467b*) and two remaining miRNAs exhibited higher expression (mmu-miR-291b-5p and mmu-miR-296-5p) compared to control. Moreover, the authors discovered an interesting phenomenon. The ApoE miRNA signature was partially reversed by polyphenols, including quercetin toward the wild type signature ${ }^{83}$.

Another interesting finding is the effect of quercetin, exercise or their combination on miRNA expression and their interaction with an atherogenic diet. Authors used C57BL/6J LDL $\mathrm{LD}^{-/-}$mice. miRNAs expression was assessed in aorta and liver tissues. Experiments suggested upregulation of miR-21 in the aorta after exercise and quercetin/ exercise group. Aorta miR-125b was also upregulated in the quercetin/exercise group. However, miR-451 showed non-significant changes in the same tissue. In the liver tissue, expression of miR-21 displayed the same expression pattern as for the aorta. Moreover, quercetin slightly potentiated the effect of exercise on liver miR-21 expression, but quercetin monotherapy was not effective. On the other hand, exercise decreased expression of miR-451 in the liver and combination with quercetin reduced the effect of exercise. Quercetin alone caused non-significant downregulation. miR-125b in the liver samples displayed almost no effect of quercetin but the same compound in combination with exercise mildly attenuated (non-significant) the exercise induced upregulation of miR-125b. Quite a few of these results were trends ${ }^{84}$.

Boesch-Saadatmandi and colleagues published a paper in 2012 describing two other miRNAs regulated by quercetin achieved with in vivo experiment. They used a female mouse model C57BL/6J with chronic subacute inflammation induced by a high fat diet. Liver miR-122 and miR-125b were upregulated dose dependently after six weeks of consumption of the quercetin containing diet. 
Table 1. Summary of quercetin mediated miRNAs with modulated targets and treatment characteristics - in vitro. The values for miRNA expression were usually estimated from article graphs

\begin{tabular}{|c|c|c|c|c|c|c|}
\hline \multicolumn{7}{|c|}{ In vitro } \\
\hline 苑 & 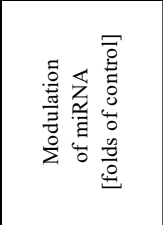 & 吾 & 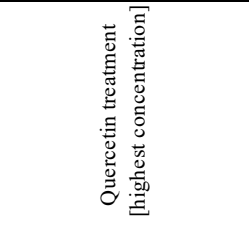 & 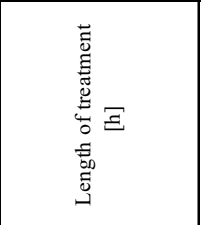 & 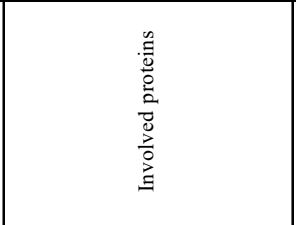 & 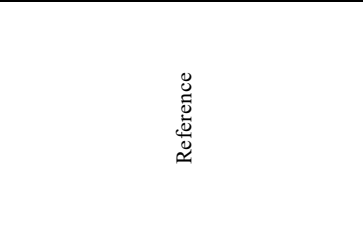 \\
\hline \multirow{2}{*}{ miR-146a } & $\uparrow 4.0$ & MCF-7 & \multirow{2}{*}{$100 \mu \mathrm{m} / \mathrm{ml}$} & \multirow{2}{*}{48} & \multirow{2}{*}{ Bax $\uparrow$, Caspase-3 $\uparrow$, EGFR $\downarrow$} & \multirow{2}{*}{ Tao et al., 2015 (ref. $^{57}$ ) } \\
\hline & $\uparrow 4.5$ & MDA-MB-231 & & & & \\
\hline miR-146a & $\begin{array}{c}\uparrow \text { restore } \\
\text { to control } \\
\text { level or exceed it }\end{array}$ & CCD-18Co & $\begin{array}{c}\text { undetermined } \dagger \\
20-40 \mathrm{mg} \mathrm{GAE} / \mathrm{L} \\
\text { (flavonol-rich fraction) }\end{array}$ & \begin{tabular}{|c|} 
Pretreatment \\
30 min before \\
stimulation with LPS \\
or LPS + anti-miR \\
\end{tabular} & $\begin{array}{c}\text { proposal } \\
\text { (not directly confirmed) } \\
\text { IRAK1 } \downarrow \text { and TRAF6 } \downarrow\end{array}$ & Noratto et al., 2011 (ref. $^{37}$ ) \\
\hline $\operatorname{miR}-27 \mathrm{a}$ & $\downarrow 2.0$ & HT-29 & $\begin{array}{c}20 \mu \mathrm{g} / \mathrm{ml} \\
\text { (resveratrol/quercetin mixture) }\end{array}$ & 24 & ZBTB10 (mRNA level) $\uparrow$ & Del Follo-Martinez et al., 2013 (ref. ${ }^{62}$ ) \\
\hline $\operatorname{miR}-27 \mathrm{a}$ & $\downarrow 2.0$ & $786-\mathrm{O}$ & $\begin{array}{c}20 \mu \mathrm{g} / \mathrm{ml} \\
\text { (quercetin/hyperoside mixture) }\end{array}$ & 24 & ZBTB10 (mRNA level) $\uparrow$ & Li et al., 2014 (ref. ${ }^{63}$ ) \\
\hline miR-21 & $\downarrow 4.3(77 \%)$ & $\mathrm{PC} 3$ & $\begin{array}{c}20 \mu \mathrm{g} / \mathrm{ml} \\
\text { (quercetin/hyperoside mixture) }\end{array}$ & 24 & $\mathrm{PDCD} 4 \uparrow$ & Yang et al., 2015 (ref. $^{64}$ ) \\
\hline miR-19b & $\downarrow 3.4$ & \multirow{3}{*}{ LAPC-4 } & \multirow{3}{*}{$\begin{array}{l}1 \mu \mathrm{M} \text { - Arctigenin } \\
10 \mu \mathrm{M} \text { - Quercetin }\end{array}$} & \multirow{12}{*}{48} & \multirow{3}{*}{ no direct confirmation } & \multirow{12}{*}{ Wang et al., 2015 (ref. $^{65}$ ) } \\
\hline miR-21 & $\downarrow 1.7$ & & & & & \\
\hline miR-148a & $\downarrow 3.5$ & & & & & \\
\hline miR-19b & $\downarrow 1.2$ & \multirow{3}{*}{$\mathrm{LNCaP}$} & \multirow{3}{*}{$\begin{array}{c}1 \mu \mathrm{M} \text { - Arctigenin } \\
10 \mu \mathrm{M} \text { - Quercetin }\end{array}$} & & \multirow{3}{*}{ no direct confirmation } & \\
\hline $\operatorname{miR}-21$ & $\downarrow 1.3$ & & & & & \\
\hline miR-148a & $\downarrow 1.5$ & & & & & \\
\hline miR-19b & $\downarrow 1.45$ & \multirow{3}{*}{ LAPC-4 } & \multirow{3}{*}{$10 \mu \mathrm{M}$ - Quercetin } & & \multirow{3}{*}{ no direct confirmation } & \\
\hline $\operatorname{miR}-21$ & $\uparrow 1.4$ & & & & & \\
\hline miR-148a & $\downarrow 1.5$ & & & & & \\
\hline miR-19b & $\downarrow 1.75$ & & & & & \\
\hline miR-21 & $\uparrow 1.7$ & $\mathrm{LNCaP}$ & $10 \mu \mathrm{M}$ - Quercetin & & no direct confirmation & \\
\hline miR-148a & $\downarrow 1.05$ & & & & & \\
\hline miR-21 & $\downarrow 1.8$ & MCF-7 & $10 \mu \mathrm{M}$ & 24 & $\begin{array}{l}\mathrm{PTEN} \uparrow \text { and Maspin } \uparrow \\
\text { (not directly confirmed) }\end{array}$ & Tofigh et al., 2017 (ref. $^{67}$ ) \\
\hline miR-21 & $\downarrow 3.0^{\mathrm{x}}$ & & $10 \mu \mathrm{M}\left(+5 \mu \mathrm{M} \mathrm{Cr}^{\mathrm{VI+}}\right)$ & 24 (acute) & PDCD4 $\uparrow$ & \\
\hline & $\downarrow 2.1^{x}$ & BEAS-2B & & 2 months & PDCD4 $\uparrow$ & Pratheeshkumar et al., $2017\left(\right.$ ref. $^{68}$ ) \\
\hline $\operatorname{miR}-21$ & $2.5^{\mathrm{x}}$ & DEAD-ZD & $2 \mu \mathrm{M}\left(+0.5 \mu \mathrm{M} \mathrm{Cr}^{\mathrm{VI+}+}\right)$ & 4 months & PDCD4 $\uparrow$ & Pratneesnkumar et al., 201/ (ret. ) \\
\hline & $\downarrow 4.3^{x}$ & & & 6 months & PDCD4 $\uparrow$ & \\
\hline miR-21-5p & $\downarrow 1.4^{y}$ & HK-2 & $15 \mathrm{mg} / \mathrm{ml}(50 \mathrm{mM})$ & 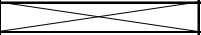 & $\mathrm{PTEN} \uparrow$ and TIMP $3 \uparrow$ & Cao et al., 2018 (ref. ${ }^{69}$ ) \\
\hline miR-155 & $\downarrow \sim 1.8^{*}$ & RAW264.7 & $10 \mu \mathrm{M}$ & 6 & $\begin{array}{c}\text { proposal TNF- } \alpha \\
\text { (not directly confirmed) }\end{array}$ & Boesch-Saadatmandi et al., $2011\left(\right.$ ref. $\left.^{70}\right)$ \\
\hline & $\uparrow 2.45$ & MIA-PaCa2 & & & & \\
\hline & $\uparrow 1.6$ & BxPC-3 & 200 M - Ouercetin & & & \\
\hline & $\uparrow 1.45$ & PacaDD-183 & & & & \\
\hline & $\uparrow 1.35 \#$ & CRL1097 & & & K-Ras $\downarrow$ (mRNA level) & \\
\hline & $\uparrow 3.0$ & MIA-PaCa2 & & & $\begin{array}{c}K-K a s \downarrow \text { (miNA lever) } \\
\text { (protein level showed exceptions }\end{array}$ & \\
\hline let-7a & $\uparrow 2.3$ & BxPC-3 & $10 \mu \mathrm{M}$ - Sulforaphane & 72 & after sulforaphane, guercetin & Appariet al $2014\left(\mathrm{ref}^{71}\right)$ \\
\hline & $\uparrow 2.45$ & PacaDD-183 & $200 \mu \mathrm{M}$ - Quercetin & 12 & treatment) & \\
\hline & $\uparrow 1.5 \#$ & CRL1097 & & & (not directly confirmed) & \\
\hline & $\uparrow 3.2$ & MIA-PaCa2 & & & & \\
\hline & $\uparrow 3.1$ & BxPC-3 & $40 \mu \mathrm{M}$ - green tea extract & & & \\
\hline & $\uparrow 3.1$ & PacaDD-183 & $200 \mu \mathrm{M}$ - Quercetin & & & \\
\hline & $\uparrow 1.6 \#$ & CRL1097 & & & & \\
\hline & $\uparrow 1.8$ & AsPC-1 & & & Numb $\uparrow$ & \\
\hline let-7c & $\uparrow 1.3$ & ASANPaCa & & & no direct confirmation & \\
\hline & $\uparrow 1.9$ & PANC-1 & & & no direct contrimation & \\
\hline miR-200b & $\uparrow 2.6$ & & $50 u \mathrm{M}$ & 12 & Notch $\downarrow$ & Nwaeburu et al., 2016 (ref. ${ }^{73}$ ) \\
\hline miR-200a & $\uparrow 2.1$ & & & 12 & & Nwaeburu et al., 2017 (ref. $^{74}$ ) \\
\hline miR-103 & $\downarrow 1.3$ & AsPC-1 & & & no direct confirmation & \\
\hline miR-125b & $\downarrow 1.4$ & & & & no direct confirmation & \\
\hline miR-1202 & $\downarrow 3.3$ & & & & & \\
\hline miR-17-3p & $\uparrow$ over 1.5 & Caco-2 TC7 & $10 \mu \mathrm{M}$ & 18 & $\begin{array}{c}\text { Ferroportin } \downarrow \\
\text { (not directly confirmed) }\end{array}$ & Lesjak et al., 2014 (ref. $^{75}$ ) \\
\hline miR-16 & $\uparrow 1.4$ & A549 & $50 \mu \mathrm{M}$ & 24 & Claudin- $2 \downarrow$ & Sonoki et al., 2015 (ref. $^{77}$ ) \\
\hline & $\uparrow 1.45$ & & $5, \mathrm{M}-$ Ourcetin & 24 & & \\
\hline miR 2017 & $\uparrow 1.8$ & $143 \mathrm{~B}$ & $5 \mu \mathrm{M}$ - Quercetin & 48 & K-Ras & \\
\hline mik-21/7 & $\uparrow 2.9$ & $143 \mathrm{~B}$ & $5 \mu \mathrm{M}$ - Quercetin & 24 & K-Ras $\downarrow$ & Zhang et al., 2015 (ref. ${ }^{\circ}$ ) \\
\hline & $\uparrow 3.5$ & & $5 \mu \mathrm{M}$ - Cisplatin & 48 & & \\
\hline & $\uparrow 3.1$ & MIA-PaCa2 & & & no direct confirmation & \\
\hline $\operatorname{miR}-142-3 p$ & $\uparrow 7.6$ & Capan-1 & $100 \mu \mathrm{M}$ & 24 & with quercetin & MacKenzie et al., 2013 (ref. $^{79}$ ) \\
\hline & $\uparrow 3.4$ & S2-013 & & & $($ HSP70 $\downarrow)$ & \\
\hline $\operatorname{miR}-145$ & $\uparrow 3.0$ & SKOV-3 & $100 \mu \mathrm{m} / \mathrm{ml}$ & 24 & Caspase- $3 \uparrow$ & Zhou et al $2015\left(\operatorname{ref}^{80}\right)$ \\
\hline mIIR-14J & $\uparrow 3.5$ & A2780 & $100 \mathrm{\mu m} / \mathrm{ml}$ & 24 & (growth inhibition) & Zhou et al., 2015 (ret." ) \\
\hline
\end{tabular}

* Against positive LPS treatment

$\uparrow$ Authors determined amount of polyphenols in the fraction via total reduction capacity and gallic acid was used as standard (20 mg GAE/L $=\mathrm{mg}$ gallic acid equivalents $/ \mathrm{L}$ )
Proposal $=$ not confirmed directly in the article. For example via antimiR experiment

\# = not statistically significant

$\mathrm{X}=$ compared to $\mathrm{Cr}^{\mathrm{VI}+}$ treated cells

$\mathrm{y}=$ compared to TGF- $\beta$ treated cells 
$2 \mathrm{mg}$ quercetin/g diet caused 1.6 to 1.5 -fold upregulation, $0.2 \mathrm{mg}$ quercetin/g diet only resulted in non-significant enhancement ${ }^{85}$.

\section{Patient samples}

The last set of findings is based on an epidemiologic study of Lung cancer tissues. The question was whether a quercetin-rich diet can modulate miRNA expression. Data presented in this study showed that there is a group of miRNAs which was significantly upregulated (2 miRNAs/4 miRNAs) or downregulated (2 miRNAs /8 miRNAs) in adenocarcinoma/squamous cell carcinoma between groups consuming high and low quantities of quercetin-rich food (see Table 3). The authors applied an advanced complex sorting based on former/current smoking + histology or sorting according to miRNA families in combined with smoking status and histology ${ }^{86}$.

\section{Quercetin glycosides and its derivatives}

Scientists are interested in derivatives of quercetin such as rhamnetin that modulates miR-34a in different cell lines ${ }^{87-89}$. Finally, we found an article, which reversed the usual logic. The authors used miR-143 as a molecule that increases chemosensitivity to quercetin in gastric can-

Table 2. Summary of quercetin mediated miRNAs with modulated targets and treatment dose of the compound characteristics - in vivo. The values for miRNA expression were usually estimated from article graphs.

\begin{tabular}{|c|c|c|c|c|c|c|}
\hline \multicolumn{7}{|c|}{ In vivo } \\
\hline 尝 & 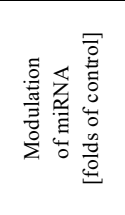 & $\begin{array}{l}\bar{\Xi} \\
\bar{\Sigma}\end{array}$ & 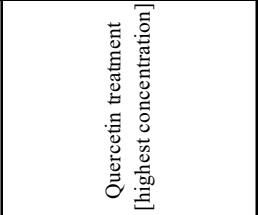 & 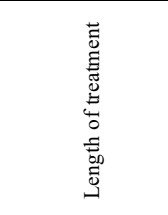 & 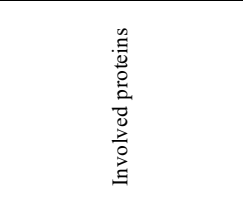 & 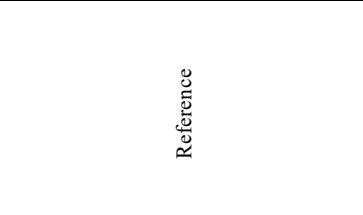 \\
\hline miR-146a & $\uparrow$ over 1.75 & $\begin{array}{c}\text { female BALB/c } \\
\text { athymic nude } \\
\text { mouse (xenograft) }\end{array}$ & $10 \mathrm{mg} / \mathrm{kg}$ per day & 8 weeks & $\begin{array}{l}\text { authors only compare } \\
\text { size of tumor and } \\
\text { miR-146a expression }\end{array}$ & Tao et al., 2015 (ref. $^{57}$ ) \\
\hline \multirow{2}{*}{ miR-21 } & $\downarrow 1.5$ & \multirow{2}{*}{$\begin{array}{c}\text { female } \mathrm{NU} / \mathrm{NU} \text { Athymic } \\
\text { nude mouse }\end{array}$} & $\begin{array}{c}\text { CrT cells injected into flank } \\
10 \mathrm{mg} / \mathrm{kg} \text { per day } \\
\text { ip administration }\end{array}$ & 30 days & \multirow{2}{*}{ PDCD4 $\uparrow$} & \multirow{2}{*}{ Pratheeshkumar et al., $2017\left(\right.$ ref. $^{68}$ ) } \\
\hline & $\downarrow 1.7^{\mathrm{x}}$ & & \begin{tabular}{|c|} 
pretreated BEAS-2B cells \\
injected into flank \\
$2 \mu \mathrm{M}\left(+0.5 \mu \mathrm{M} \mathrm{Cr}^{\mathrm{Vl+}}\right)$ \\
\end{tabular} & $\begin{array}{c}\text { pretreatment of } \\
\text { BEAS-2B cells } \\
6 \text { months } \\
\end{array}$ & & \\
\hline $\operatorname{miR}-125 b-3 p$ & $\downarrow 9$ & \multirow{17}{*}{ male Wistar rat } & \multirow{17}{*}{$\begin{array}{c}10 \mathrm{mg} / \mathrm{kg} \text { per day } \\
(100-\mathrm{ppm} \text { quercetin) }\end{array}$} & \multirow{17}{*}{7 weeks } & $\begin{array}{l}\gamma \text {-glutamyl hydrolase } \\
\text { (not directly confirmed) }\end{array}$ & \multirow{17}{*}{ Wein et al., 2015 (ref. ${ }^{81}$ ) } \\
\hline miR-133b & $\downarrow 7$ & & & & \multirow{16}{*}{ not stated } & \\
\hline miR-505 & $\downarrow 7$ & & & & & \\
\hline miR-1 & $\downarrow 6$ & & & & & \\
\hline $\mathrm{miR}-342-3 \mathrm{p}$ & $\downarrow 5$ & & & & & \\
\hline miR-298 & $\downarrow 5$ & & & & & \\
\hline miR-503 & $\downarrow 4$ & & & & & \\
\hline miR-206 & $\downarrow 4$ & & & & & \\
\hline miR-33 & $\downarrow 4$ & & & & & \\
\hline miR-216a & $\downarrow 4$ & & & & & \\
\hline miR-301a & $\downarrow 3$ & & & & & \\
\hline miR-21 & $\downarrow 3$ & & & & & \\
\hline miR-205 & $\downarrow 3$ & & & & & \\
\hline miR-125a-3p & $\uparrow 5$ & & & & & \\
\hline miR-132 & $\uparrow 5$ & & & & & \\
\hline miR-411 & $\uparrow 4$ & & & & & \\
\hline miR-484 & $\uparrow 3$ & & & & & \\
\hline 25 miRNAs & $\uparrow$ over 1.5 & \multirow{2}{*}{$\begin{array}{l}\text { wild-type and apoE } \\
\text { knock-out mouse } \\
\text { (male, C57BL/6) }\end{array}$} & \multirow{2}{*}{$\begin{array}{l}0.006 \%(\mathrm{w} / \mathrm{w}) \\
\text { (human equivalent } \\
\text { intake } 30 \mathrm{mg} / \text { day) }\end{array}$} & \multirow{2}{*}{2 weeks } & \multirow{2}{*}{$\begin{array}{l}\text { several pathway discused } \\
\text { (not directly confirmed) }\end{array}$} & \multirow{2}{*}{ Milenkovic et al., $2012\left(\right.$ ref. $\left.^{83}\right)$} \\
\hline 22 miRNAs & $\downarrow$ over 1.5 & & & & & \\
\hline \multirow{2}{*}{$\begin{array}{c}\text { miR-21 } \\
\text { aorta }\end{array}$} & $\uparrow 1.2$ & \multirow{12}{*}{$\begin{array}{c}\text { male } \mathrm{C} 57 \mathrm{BL} / 6 \mathrm{~J} \mathrm{LDL}^{-1-} \\
\text { mouse }\end{array}$} & $100 \mu \mathrm{g} /$ day & \multirow{12}{*}{30 days } & \multirow{7}{*}{ no direct confirmation } & \multirow{12}{*}{ Garelnabi et al., $2014\left(\right.$ ref. $\left.^{84}\right)$} \\
\hline & $\uparrow 1.85$ & & $100 \mu \mathrm{g} /$ day + exercise & & & \\
\hline miR-21 & $\downarrow 1.12$ & & $100 \mu \mathrm{g} /$ day & & & \\
\hline liver & $\uparrow 2.0$ & & $100 \mu \mathrm{g} /$ day + exercise & & & \\
\hline miR-125b & $\downarrow 1.1$ & & $100 \mu \mathrm{g} / \mathrm{day}$ & & & \\
\hline aorta & $\uparrow 1.79$ & & $100 \mu \mathrm{g} /$ day + exercise & & & \\
\hline & $\downarrow 1.26$ & & $100 \mu \mathrm{g} /$ day & & & \\
\hline $\begin{array}{l}\text { miR-125b } \\
\text { liver }\end{array}$ & $\uparrow 2.77$ & & $100 \mu \mathrm{g} /$ day + exercise & & $\begin{array}{l}\text { STAT3 } \downarrow \text { and NF-kB } \uparrow \\
\text { (Data not shown, } \\
\text { discussed in the text) }\end{array}$ & \\
\hline $\mathrm{miR}-451$ & $\uparrow 2.0$ & & $100 \mu \mathrm{g} /$ day & & \multirow{4}{*}{ no direct confirmation } & \\
\hline aorta & $\downarrow 1.1$ & & $100 \mu \mathrm{g} /$ day + exercise & & & \\
\hline miR-451 & $\downarrow 1.4$ & & $100 \mu \mathrm{g} /$ day & & & \\
\hline liver & $\downarrow 2.03$ & & $100 \mu \mathrm{g} /$ day + exercise & & & \\
\hline miR-122 & $\uparrow 1.6$ & \multirow{2}{*}{$\begin{array}{l}\text { female C57BL/6J } \\
\text { mouse (liver) }\end{array}$} & \multirow[t]{2}{*}{0.2 and $2 \mathrm{mg} / \mathrm{g}$ diet } & \multirow[t]{2}{*}{6 weeks } & $\begin{array}{l}\text { acyloxyacyl hydrolase } \downarrow \\
\text { (not directly confirmed) }\end{array}$ & \multirow[t]{2}{*}{ Boesch-Saadatmandi et al., 2012 (ref. ${ }^{85}$ ) } \\
\hline miR-125b & $\uparrow 1.5$ & & & & TNF- $\alpha \downarrow$ (speculation) & \\
\hline
\end{tabular}

ip = intraperitoneal

$\mathrm{X}=$ compared to $\mathrm{Cr}^{\mathrm{VI}+}$ treated cells

CrT $=$ chromium transformed cells 
Table 3. Summary of quercetin mediated miRNAs with modulated targets and treatment characteristics - patient samples.

\begin{tabular}{|c|c|c|c|c|c|c|}
\hline \multicolumn{7}{|c|}{ Patient samples } \\
\hline 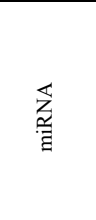 & 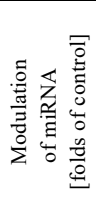 & $\begin{array}{l}\frac{\vec{d}}{0} \\
\frac{0}{2}\end{array}$ & 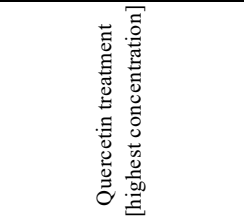 & 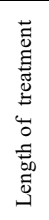 & 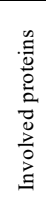 & 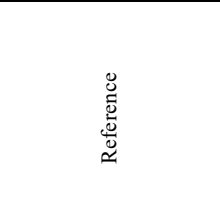 \\
\hline miR-502 & $\uparrow 1.124$ & \multirow{4}{*}{$\begin{array}{c}\text { Lung adenocarcinoma } \\
\text { tissues }\end{array}$} & \multirow{16}{*}{$\begin{array}{l}\text { Statistically different } \\
\text { expression between high } \\
\text { and low Que diet only } \\
\text { (Highest/lowest quercetin- } \\
\text { rich food consumers) }\end{array}$} & & & \multirow{16}{*}{ Lam et al., $2012\left(\right.$ ref. $\left.^{86}\right)$} \\
\hline miR-125a & $\uparrow 1.505$ & & & & & \\
\hline miR-564 & $\downarrow 1.124$ & & & & & \\
\hline miR-124a & $\downarrow 1.174$ & & & & & \\
\hline miR-155 & $\uparrow 1.399$ & \multirow{12}{*}{$\begin{array}{l}\text { Lung squamous cell } \\
\text { carcinoma tissues }\end{array}$} & & & & \\
\hline miR-18b & $\uparrow 1.483$ & & & & & \\
\hline miR-612 & $\uparrow 1.069$ & & & & & \\
\hline miR-363* & $\uparrow 1.222$ & & & & & \\
\hline miR-510 & $\downarrow 1.147$ & & & & & \\
\hline miR-605 & $\downarrow 2.315$ & & & & & \\
\hline miR-373 & $\downarrow 1.091$ & & & & & \\
\hline miR-453 & $\downarrow 1.112$ & & & & & \\
\hline miR-502 & $\downarrow 1.248$ & & & & & \\
\hline miR-183 & $\downarrow 1.464$ & & & & & \\
\hline miR-573 & $\downarrow 1.151$ & & & & & \\
\hline miR-524* & $\downarrow 1.170$ & & & & & \\
\hline
\end{tabular}

cer cells via autophagy inhibition. The autophagy inhibition was mediated by GABARAPL1, a miR-143 target $^{90}$.

\section{CONCLUSION}

We found a total of ninety-five different species of miRNA affected by quercetin in our literature research. Of these, 18 miRNAs were revealed as deregulated in in vitro experiments, 66 through in vivo experiments and finally, 15 were discovered in human tissue samples. Several miRNA molecules were expressed with a common pattern among in vitro and in vivo experiments as a result of quercetin treatment. miR-21 in particular was deregulated in the same manner (downregulation) in MCF-7, BEAS-2B and HK-2 cell lines and in two in vivo models (mouse/ rat $)^{67-69,81}$. The literature search identified a few exceptions in two articles that reported quercetin mediated upregulation of miR-21 in the majority of samples ${ }^{65,84}$. Interestingly, quercetin causes modulation of let-7c and miR-200b in the same cell line and it seems that these miRNAs cooperate $^{73,74}$. The data suggest synergy in potential anti-cancer effects against pancreatic ductal cell adenocarcinoma. Further, the patient samples described in Lam et al. ${ }^{86}$ study, displayed ambiguous expression of miR-502 that was upregulated in lung adenocarcinoma tissues but lung squamous cell carcinoma tissues showed downregulation of the expression when tissues from highest/lowest quercetin-rich food consumers were compared ${ }^{86}$.

Some miRNA molecules can serve as predictive markers of cancers, especially miR-21 and let-7 family ${ }^{91}$ that are modulated by quercetin. MiR-21 is commonly recognized as oncogenic and as an unfavorable prognostic factor $^{91,92}$. As expected, its expression was evaluated in many studies and quercetin or combination treatment usually downregulate miR-21 expression regardless of the tested model (in vitro/in vivo). The let-7 family, on the other hand, is widely viewed as a tumor suppressor miRNAs ${ }^{91,93}$.
Different members of the miRNA family are often upregulated by quercetin treatment. Shin et al. ${ }^{91}$ discuss miR-27a as a diagnostic marker of gastric cancer and miR-146a as gastric cancer-associated miRNA ( ref. $^{91}$ ). Both miRNAs are modulated by quercetin. These results suggest that quercetin could function prophylactically in cancer prevention (e.g. in nutraceutics) with minor exceptions, e.g. Wang et al. ${ }^{65}$ - quercetin only treatment enhanced expression of miR-21.

Many of the studies published used high concentrations, usually several tens of $\mu \mathrm{M}$ that are not physiologically achievable per os from a regular diet. The data could be viewed as an interesting option for adjuvant therapies.

\section{ABBREVIATIONS}

DMSO, Dimethyl sulfoxide; PBS, Phosphate-buffered saline; ROS, Reactive oxygen species; LPH, Lactase phloridzin hydrolase; RISC, RNA-induced silencing complex; DGCR8, DiGeorge syndrome critical region 8; LPS, Lipopolysaccharide; AhR, Aryl hydrocarbon receptor; miRNA, micro ribonucleic acid; CYP, Cytochrome P450; mRNA, messenger ribonucleic acid; GAE/L, Gallic acid equivalents per liter; TGF- $\beta$, Transforming growth factor $\beta$; TCDD, 2,3,7,8-Tetrachlorodibenzodioxin; TRBP, TransActivation Responsive RNA-Binding Protein; BRCA1/2, Breast cancer type 1/2 susceptibility protein; EGFR, Epidermal growth factor receptor; IRAK-1, Interleukin-1 receptor associated kinase 1; TRAF-6, Tumor necrosis factor receptor associated factor 6; TLR pathway, Tolllike receptor pathway; ZBTB10, Zinc Finger And BTB Domain-Containing Protein 10; Sp transcription factors, Specificity protein transcription factors; PDCD4, Programmed cell death protein 4; PTEN, Phosphatase and tensin homolog; Maspin, Mammary serine protease inhibitor; NF-кB, Nuclear Factor Kappa B; PCR, Polymerase chain reaction; RT, Room temperature. 


\section{Search strategy and selection criteria}

Our article focuses on the miRNA modulation as impact of quercetin treatment or combination of compounds containing quercetin. Minor emphasis was placed on pharmacokinetics of quercetin and miRNA biogenesis. The scientific articles from 1972 to 2019 were searched using the PubMed and Google Scholar. All the documents were searched through keywords such as "Quercetin, miRNA, modulation, microRNA, regulation and polyphenols”. Only English language articles were reviewed.

Acknowledgement: This work was supported by IGA LF_2019_015 and the Institutional Support of Palacký University in Olomouc RVO 61989592. The authors are thankful to Dr. A.V. Zholobenko for proofreading of the manuscript.

Author contribution: All authors contributed equally to preparing the manuscript.

Conflict of interest statement: The authors state that there are no conflicts of interest regarding the publication of this article.

\section{REFERENCES}

1. Ovaskainen ML, Torronen R, Koponen JM, Sinkko H, Hellstrom J, Reinivuo H, Mattila P. Dietary intake and major food sources of polyphenols in Finnish adults. J Nutr 2008;138(3):562-6. doi: 10.1093/ jn/138.3.562

2. Grosso G, Stepaniak U, Topor-Madry R, Szafraniec K, Pajak A. Estimated dietary intake and major food sources of polyphenols in the Polish arm of the HAPIEE study. Nutrition 2014;30(11-12):1398 403. doi: 10.1016/j.nut.2014.04.012

3. Bravo L. Polyphenols: Chemistry, dietary sources, metabolism, and nutritional significance. Nutr Rev 1998;56(11):317-33.

4. Di Ferdinando M, Brunetti C, Agati G, Tattini M. Multiple functions of polyphenols in plants inhabiting unfavorable Mediterranean areas. Environ Exp Bot 2014;103:107-16. doi: 10.1016/j.envexpbot.2013.09.012

5. Hussain T, Tan B, Yin YL, Blachier F, Tossou MCB, Rahu N. Oxidative Stress and Inflammation: What Polyphenols Can Do for Us? Oxid Med Cell Longev 2016. doi: 10.1155/2016/7432797

6. Moosavi F, Hosseini R, Saso L, Firuzi O. Modulation of neurotrophic signaling pathways by polyphenols. Drug Des Dev Ther 2016;10:2342. doi: 10.2147/DDDT.S96936

7. Mansuri ML, Parihar P, Solanki I, Parihar MS. Flavonoids in modulation of cell survival signalling pathways. Genes Nutr 2014;9(3). doi: 10.1007/S12263-014-0400-Z

8. Akiyama T, Ishida J, Nakagawa S, Ogawara H, Watanabe S, Itoh N, Shibuya M, Fukami Y. Genistein, a specific inhibitor of tyrosine-specific protein kinases. J Biol Chem 1987;262(12):5592-5.

9. Kelly GS. Quercetin. Monograph. Altern Med Rev 2011;16(2):172-94.

10. Cao J, Zhang Y, Chen W, Zhao XJ. The relationship between fasting plasma concentrations of selected flavonoids and their ordinary dietary intake. Brit J Nutr 2010;103(2):249-55. doi: 10.1017/ S000711450999170x

11. Kawabata K, Mukai R, Ishisaka A. Quercetin and related polyphenols: new insights and implications for their bioactivity and bioavailability. Food Funct 2015;6(5):1399-417. doi: 10.1039/c4fo01178c

12. D'Andrea G. Quercetin: A flavonol with multifaceted therapeutic applications? Fitoterapia 2015;106:256-71. doi: 10.1016/j.fitote.2015.09.018.

13. Wang WY, Sun CX, Mao LK, Ma PH, Liu FG, Yang J, Gao YX. The biological activities, chemical stability, metabolism and delivery systems of quercetin: A review. Trends Food Sci Tech 2016;56:21-38. doi: 10.1016/j.tifs.2016.07.004

14. Kiviranta J, Huovinen K, Hiltunen R. Variation of phenolic substances in onion. Acta Pharm Fenn 1988;97:67-72.
15. Fang N, Yu SG, Mabry TJ. Flavonoids from Ageratina-Calophylla. Phytochemistry 1986;25(11):2684-6. doi: 10.1016/S00319422(00)84545-8

16. Day AJ, DuPont MS, Ridley S, Rhodes M, Rhodes MJ, Morgan MR, Williamson G. Deglycosylation of flavonoid and isoflavonoid glycosides by human small intestine and liver beta-glucosidase activity. FEBS Lett 1998;436(1):71-5. doi: 10.1016/S0014-5793(98)01101-6

17. Walle T, Browning AM, Steed LL, Reed SG, Walle UK. Flavonoid glucosides are hydrolyzed and thus activated in the oral cavity in humans. J Nutr 2005;135(1):48-52. doi: 10.1093/jn/135.1.48

18. McDonald MS, Hughes M, Burns J, Lean ME, Matthews D, Crozier A. Survey of the Free and Conjugated Myricetin and Quercetin Content of Red Wines of Different Geographical Origins. J Agric Food Chem 1998;46(2):368-75.

19. Ferry DR, Smith A, Malkhandi J, Fyfe DW, deTakats PG, Anderson D, Baker J, Kerr DJ. Phase I clinical trial of the flavonoid quercetin: pharmacokinetics and evidence for in vivo tyrosine kinase inhibition. Clin Cancer Res 1996;2(4):659-68.

20. Priprem A, Watanatorn J, Sutthiparinyanont S, Phachonpai W, Muchimapura S. Anxiety and cognitive effects of quercetin liposomes in rats. Nanomedicine 2008;4(1):70-8. doi: 10.1016/j. nano.2007.12.001

21. Gao L, Liu G, Wang X, Liu F, Xu Y, Ma J. Preparation of a chemically stable quercetin formulation using nanosuspension technology. Int J Pharm 2011;404(1-2):231-7. doi: 10.1016/j.ijpharm.2010.11.009

22. Gugler R, Leschik M, Dengler HJ. Disposition of quercetin in man after single oral and intravenous doses. Eur J Clin Pharmacol 1975;9(23):229-34.

23. Manach C, Scalbert A, Morand C, Remesy C, Jimenez L. Polyphenols: food sources and bioavailability. Am J Clin Nutr 2004;79(5):727-47. doi: 10.1093/ajcn/79.5.727

24. Kuhnau J. The flavonoids. A class of semi-essential food components: their role in human nutrition. World Rev Nutr Diet 1976;24:117-91.

25. Griffiths $L A$, Barrow A. Metabolism of flavonoid compounds in germfree rats. Biochem J 1972;130(4):1161-2.

26. Walle T, Walle UK, Halushka PV. Carbon dioxide is the major metabolite of quercetin in humans. J Nutr 2001;131(10):2648-52. doi: 10.1093/jn/131.10.2648

27. Ueno I, Nakano N, Hirono I. Metabolic fate of [14C] quercetin in the ACl rat. Jpn J Exp Med 1983;53(1):41-50.

28. Zhang Z, Peng X, Li S, Zhang N, Wang Y, Wei H. Isolation and identification of quercetin degrading bacteria from human fecal microbes. PLoS One 2014;9(3):e90531. doi: 10.1371/journal.pone.0090531

29. Day AJ, Canada FJ, Diaz JC, Kroon PA, McLauchlan R, Faulds CB, Plumb GW, Morgan MR, Williamson G. Dietary flavonoid and isoflavone glycosides are hydrolysed by the lactase site of lactase phlorizin hydrolase. FEBS Lett 2000;468(2-3):166-70. doi: 10.1016/ S0014-5793(00)01211-4

30. Aziz AA, Edwards CA, Lean ME, Crozier A. Absorption and excretion of conjugated flavonols, including quercetin-4'-O-beta-glucoside and isorhamnetin-4'-O-beta-glucoside by human volunteers after the consumption of onions. Free Radic Res 1998;29(3):257-69. doi: $10.1080 / 10715769800300291$

31. Hollman PC, de Vries JH, van Leeuwen SD, Mengelers MJ, Katan $\mathrm{MB}$. Absorption of dietary quercetin glycosides and quercetin in healthy ileostomy volunteers. Am J Clin Nutr 1995;62(6):1276-82. doi: 10.1093/ajcn/62.6.1276

32. Walle T, Otake Y, Walle UK, Wilson FA. Quercetin glucosides are completely hydrolyzed in ileostomy patients before absorption. J Nutr 2000;130(11):2658-61. doi: 10.1093/jn/130.11.2658

33. Spencer JPE, Chowrimootoo G, Choudhury R, Debnam ES, Srai SK, Rice-Evans C. The small intestine can both absorb and glucuronidate luminal flavonoids. FEBS Lett 1999;458(2):224-30. doi: 10.1016/ S0014-5793(99)01160-6

34. Graf BA, Ameho C, Dolnikowski GG, Milbury PE, Chen CY, Blumberg JB. Rat gastrointestinal tissues metabolize quercetin. J Nutr 2006;136(1):39-44. doi: 10.1093/jn/136.1.39

35. Moon YJ, Wang L, DiCenzo R, Morris ME. Quercetin pharmacokinetics in humans. Biopharm Drug Dispos 2008;29(4):205-17. doi: 10.1002/ bdd.605

36. Elbarbry F, Ung A, Abdelkawy K. Studying the Inhibitory Effect of Quercetin and Thymoquinone on Human Cytochrome P450 Enzyme Activities. Pharmacogn Mag 2018;13(Suppl 4):S895-S9. doi: 10.4103/0973-1296.224342 
37. Noratto GD, Kim Y, Talcott ST, Mertens-Talcott SU. Flavonol-rich fractions of yaupon holly leaves (Ilex vomitoria, Aquifoliaceae) induce microRNA-146a and have anti-inflammatory and chemopreventive effects in intestinal myofibroblast CCD-18Co cells. Fitoterapia 2011;82(4):557-69. doi: 10.1016/j.fitote.2011.01.013

38. Krizkova J, Burdova K, Stiborova M, Kren V, Hodek P. The effects of selected flavonoids on cytochromes $\mathrm{P} 450$ in rat liver and small intestine. Interdiscip Toxicol 2009;2(3):201-4. doi: 10.2478/v10102-0090018-y

39. Dian LH, Yu EJ, Chen XN, Wen XG, Zhang ZZ, Qin LZ, Wang QQ, L $\mathrm{G}, \mathrm{Wu} C B$. Enhancing oral bioavailability of quercetin using nove soluplus polymeric micelles. Nanoscale Res Lett 2014;9. doi: 10.1186/1556-276x-9-684

40. Conquer JA, Maiani G, Azzini E, Raguzzini A, Holub BJ. Supplementation with quercetin markedly increases plasma quercetin concentration without effect on selected risk factors for heart disease in healthy subjects. J Nutr 1998;128(3):593-7. doi: 10.1093/ jn/128.3.593

41. Lee RC, Feinbaum RL, Ambros V. The C. elegans heterochronic gene lin-4 encodes small RNAs with antisense complementarity to lin-14. Cell 1993;75(5):843-54. doi: 10.1016/0092-8674(93)90529-Y

42. Chou $\mathrm{CH}$, Chang NW, Shrestha S, Hsu SD, Lin YL, Lee WH, Yang CD, Hong HC, Wei TY, Tu SJ, Tsai TR, Ho SY, Jian TY, Wu HY, Chen PR, Lin NC, Huang HT, Yang TL, Pai CY, Tai CS, Chen WL, Huang CY, Liu CC, Weng SL, Liao KW, Hsu WL, Huang HD. miRTarBase 2016: updates to the experimentally validated miRNA-target interactions database. Nucleic Acids Res 2016;44(D1):D239-D47. doi: 10.1093/nar/gkv1258

43. Lee Y, Kim M, Han J, Yeom KH, Lee S, Baek SH, Kim VN. MicroRNA genes are transcribed by RNA polymerase II. EMBO J 2004;23(20):4051-60. doi: $10.1038 /$ sj.emboj.7600385

44. Han J, Lee Y, Yeom KH, Nam JW, Heo I, Rhee JK, Sohn SY, Cho Y, Zhang BT, Kim VN. Molecular basis for the recognition of primary microRNAs by the Drosha-DGCR8 complex. Cell 2006;125(5):887-901. doi: 10.1016/j.cell.2006.03.043

45. Lee Y, Ahn C, Han J, Choi H, Kim J, Yim J, Lee J, Provost P, Radmark O, Kim S, Kim VN. The nuclear RNase III Drosha initiates microRNA processing. Nature 2003;425(6956):415-9. doi: 10.1038/nature01957

46. Kohler A, Hurt E. Exporting RNA from the nucleus to the cytoplasm. Nat Rev Mol Cell Biol 2007;8(10):761-73. doi: 10.1038/nrm2255

47. Yi R, Qin Y, Macara IG, Cullen BR. Exportin-5 mediates the nuclear export of pre-microRNAs and short hairpin RNAs. Genes Dev 2003;17(24):3011-6. doi: 10.1101/gad.1158803

48. Bernstein E, Caudy AA, Hammond SM, Hannon GJ. Role for a bidentate ribonuclease in the initiation step of RNA interference. Nature 2001;409(6818):363-6. doi: 10.1038/35053110

49. Hutvagner G, McLachlan J, Pasquinelli AE, Balint E, Tuschl T, Zamore PD. A cellular function for the RNA-interference enzyme Dicer in the maturation of the let-7 small temporal RNA. Science 2001;293(5531):834-8. doi: 10.1126/science.1062961

50. Kwak PB, Tomari Y. The N domain of Argonaute drives duplex unwinding during RISC assembly. Nat Struct Mol Biol 2012;19(2):14551. doi: 10.1038/nsmb.2232.

51. Kim VN, Han J, Siomi MC. Biogenesis of small RNAs in animals. Nat Rev Mol Cell Biol 2009;10(2):126-39. doi: 10.1038/nrm2632

52. Schwarz DS, Hutvagner G, Du T, Xu Z, Aronin N, Zamore PD. Asymmetry in the assembly of the RNAi enzyme complex. Cell 2003;115(2):199-208. doi: 10.1016/S0092-8674(03)00759-1

53. Farazi TA, Juranek SA, Tuschl T. The growing catalog of small RNAs and their association with distinct Argonaute/Piwi family members. Development 2008;135(7):1201-14. doi: 10.1242/dev.005629

54. Parker R, Sheth U. P bodies and the control of mRNA translation and degradation. Mol Cell 2007;25(5):635-46. doi: 10.1016/j.molcel.2007.02.011

55. Ouyang M, Li Y, Ye S, Ma J, Lu L, Lv W, Chang G, Li X, Li Q, Wang S, Wang W. MicroRNA profiling implies new markers of chemoresistance of triple-negative breast cancer. PLoS One 2014;9(5):e96228. doi: 10.1371/journal.pone.0096228

56. Kollinerova S, Dostal Z, Modriansky M. MicroRNA hsa-miR-29b potentiates etoposide toxicity in HeLa cells via down-regulation of Mcl-1. Toxicol In Vitro 2017;40:289-96. doi: 10.1016/j.tiv.2017.02.005

57. Tao SF, He HF, Chen Q. Quercetin inhibits proliferation and invasion acts by up-regulating miR-146a in human breast cancer cells. Mol Cell Biochem 2015;402(1-2):93-100. doi: 10.1007/s11010-014-2317-7

58. Shen J, Ambrosone CB, DiCioccio RA, Odunsi K, Lele SB, Zhao H. A functional polymorphism in the miR-146a gene and age of familial breast/ovarian cancer diagnosis. Carcinogenesis 2008;29(10):1963-6. doi: 10.1093/carcin/bgn172

59. Li Y, Vandenboom TG, 2nd, Wang Z, Kong D, Ali S, Philip PA, Sarkar FH. miR-146a suppresses invasion of pancreatic cancer cells. Cancer Res 2010;70(4):1486-95. doi: 10.1158/0008-5472.CAN-09-2792

60. Gao W, Hua J, Jia Z, Ding J, Han Z, Dong Y, Lin Q, Yao Y. Expression of miR-146a-5p in breast cancer and its role in proliferation of breast cancer cells. Oncol Lett 2018;15(6):9884-8. doi: 10.3892/ol.2018.8589

61. Taganov KD, Boldin MP, Chang KJ, Baltimore D. NF-kappaBdependent induction of microRNA miR-146, an inhibitor targeted to signaling proteins of innate immune responses. Proc Natl Acad Sci U S A 2006;103(33):12481-6. doi: 10.1073/pnas.0605298103

62. Del Follo-Martinez A, Banerjee N, Li X, Safe S, Mertens-Talcott S. Resveratrol and quercetin in combination have anticancer activity in colon cancer cells and repress oncogenic microRNA-27a. Nutr Cancer 2013;65(3):494-504. doi: 10.1080/01635581.2012.725194

63. Li W, Liu M, Xu YF, Feng Y, Che JP, Wang GC, Zheng JH. Combination of quercetin and hyperoside has anticancer effects on renal cancer cells through inhibition of oncogenic microRNA-27a. Oncol Rep 2014;31(1):117-24. doi: 10.3892/or.2013.2811

64. Yang FQ, Liu M, Li W, Che JP, Wang GC, Zheng JH. Combination of quercetin and hyperoside inhibits prostate cancer cell growth and metastasis via regulation of microRNA21. Mol Med Rep 2015;11(2):1085-92. doi: 10.3892/mmr.2014.2813

65. Wang PW, Phan T, Gordon D, Chung S, Henning SM, Vadgama JV. Arctigenin in combination with quercetin synergistically enhances the antiproliferative effect in prostate cancer cells. Mol Nutr Food Res 2015;59(2):250-61. doi: 10.1002/mnfr.201400558

66. Frixa T, Donzelli S, Blandino G. Oncogenic MicroRNAs: Key Players in Malignant Transformation. Cancers (Basel) 2015;7(4):2466-85. doi: 10.3390/cancers7040904

67. Tofigh R, Tutunchi S, Akhavan S, Panahi G. The effects of Quercetin on miRNA-21 expression in MCF-7 cells. Arch Med Lab Sci 2017;3(3):1520.

68. Pratheeshkumar P, Son YO, Divya SP, Wang L, Turcios L, Roy RV, Hitron JA, Kim D, Dai J, Asha P, Zhang Z, Shi XL. Quercetin inhibits $\mathrm{Cr}(\mathrm{VI})$ induced malignant cell transformation by targeting miR-21-PDCD4 signaling pathway. Oncotarget 2017;8(32):52118-31. doi: 10.18632/ oncotarget.10130

69. Cao YC, Hu JL, Sui JY, Jiang LM, Cong YK, Ren GQ. Quercetin is able to alleviate TGF- $\beta$-induced fibrosis in renal tubular epithelial cells by suppressing miR-21. Exp Ther Med 2018;16(3):2442-8. doi: 10.3892/ etm.2018.6489

70. Boesch-Saadatmandi C, Loboda A, Wagner AE, Stachurska A, Jozkowicz A, Dulak J, Doring F, Wolffram S, Rimbach G. Effect of quercetin and its metabolites isorhamnetin and quercetin-3-glucuronide on inflammatory gene expression: role of miR-155. J Nutr Biochem 2011;22(3):293-9. doi: 10.1016/j.jnutbio.2010.02.008

71. Appari M, Babu KR, Kaczorowski A, Gross W, Herr I. Sulforaphane, quercetin and catechins complement each other in elimination of advanced pancreatic cancer by miR-let-7 induction and K-ras inhibition. Int J Oncol 2014;45(4):1391-400. doi: 10.3892/ijo.2014.2539

72. Johnson SM, Grosshans $H$, Shingara J, Byrom M, Jarvis R, Cheng A, Labourier E, Reinert KL, Brown D, Slack FJ. RAS is regulated by the let-7 MicroRNA family. Cell 2005;120(5):635-47. doi: 10.1016/j. cell.2005.01.014

73. Nwaeburu CC, Bauer N, Zhao Z, Abukiwan A, Gladkich J, Benner A, Herr I. Up-regulation of microRNA Let-7c by quercetin inhibits pancreatic cancer progression by activation of Numbl. Oncotarget 2016;7(36):58367-80. doi: 10.18632/oncotarget.11122

74. Nwaeburu CC, Abukiwan A, Zhao Z, Herr I. Quercetin-induced miR$200 \mathrm{~b}-3 \mathrm{p}$ regulates the mode of self-renewing divisions in pancreatic cancer. Mol Cancer 2017;16(1):23. doi: 10.1186/s12943-017-0589-8

75. Lesjak M, Hoque R, Balesaria S, Skinner V, Debnam ES, Srai SK, Sharp PA. Quercetin inhibits intestinal iron absorption and ferroportin transporter expression in vivo and in vitro. PLoS One 2014;9(7):e102900. doi: 10.1371/journal.pone.0102900

76. Ward DM, Kaplan J. Ferroportin-mediated iron transport: expression and regulation. Biochim Biophys Acta 2012;1823(9):1426-33. doi: 10.1016/j.bbamcr.2012.03.004

77. Sonoki H, Sato T, Endo S, Matsunaga T, Yamaguchi M, Yamazaki Y, Sugatani J, Ikari A. Quercetin Decreases Claudin-2 Expression Mediated by Up-Regulation of microRNA miR-16 in Lung 
Adenocarcinoma A549 Cells. Nutrients 2015;7(6):4578-92. doi: 10.3390/nu7064578

78. Zhang X, Guo Q, Chen J, Chen Z. Quercetin Enhances Cisplatin Sensitivity of Human Osteosarcoma Cells by Modulating microRNA-217-KRAS Axis. Mol Cells 2015;38(7):638-42. doi: 10.14348/molcells.2015.0037

79. MacKenzie TN, Mujumdar N, Banerjee S, Sangwan V, Sarver A, Vickers S, Subramanian S, Saluja AK. Triptolide induces the expression of miR-142-3p: a negative regulator of heat shock protein 70 and pancreatic cancer cell proliferation. Mol Cancer Ther 2013;12(7):1266-75. doi: 10.1158/1535-7163.MCT-12-1231

80. Zhou JB, Gong J, Ding C, Chen GQ. Quercetin induces the apoptosis of human ovarian carcinoma cells by upregulating the expression of microRNA-145. Mol Med Rep 2015;12(2):3127-31. doi: 10.3892/ mmr.2015.3679

81. Wein SA, Laviano A, Wolffram S. Quercetin induces hepatic gammaglutamyl hydrolase expression in rats by suppressing hepatic microRNA rno-miR-125b-3p. J Nutr Biochem 2015;26(12):1660-3. doi: 10.1016/j.jnutbio.2015.08.010

82. Shubbar E, Helou K, Kovacs A, Nemes S, Hajizadeh S, Enerback C, Einbeigi Z. High levels of gamma-glutamyl hydrolase (GGH) are associated with poor prognosis and unfavorable clinical outcomes in invasive breast cancer. BMC Cancer 2013;13:47. doi: 10.1186/1471 2407-13-47

83. Milenkovic D, Deval C, Gouranton E, Landrier JF, Scalbert A, Morand C, Mazur A. Modulation of miRNA expression by dietary polyphenols in apoE deficient mice: a new mechanism of the action of polyphenols. PLoS One 2012;7(1):e29837. doi: 10.1371/journal.pone.0029837

84. Garelnabi M, Mahini H. Modulation of microRNA 21, 125 b and 451 expression by quercetin intake and exercise in mice fed atherogenic diet. J Int Soc Sports Nutr 2014;4(3):359-63. doi: 10.1016/j. bionut.2014.04.005

85. Boesch-Saadatmandi C, Wagner AE, Wolffram S, Rimbach G. Effect of quercetin on inflammatory gene expression in mice liver in vivo
- role of redox factor 1, miRNA-122 and miRNA-125b. Pharmacol Res 2012;65(5):523-30. doi: 10.1016/j.phrs.2012.02.007

86. Lam TK, Shao S, Zhao Y, Marincola F, Pesatori A, Bertazzi PA, Caporaso $N E$, Wang $E$, Landi MT. Influence of quercetin-rich food intake on microRNA expression in lung cancer tissues. Cancer Epidemiol Biomarkers Prev 2012;21(12):2176-84. doi: 10.1158/1055-9965.EPI12-0745

87. Kang J, Kim E, Kim W, Seong KM, Youn H, Kim JW, Kim J, Youn B. Rhamnetin and cirsiliol induce radiosensitization and inhibition of epithelial-mesenchymal transition (EMT) by miR-34a-mediated suppression of Notch-1 expression in non-small cell lung cancer cell lines. J Biol Chem 2013;288(38):27343-57. doi: 10.1074/jbc. M113.490482

88. Lan L, Wang Y, Pan ZY, Wang B, Yue ZS, Jiang ZS, Li L, Wang C, Tang $\mathrm{HM}$. Rhamnetin induces apoptosis in human breast cancer cells via the miR-34a/Notch-1 signaling pathway. Oncol Lett 2019;17(1):67682. doi: $10.3892 /$ ol.2018.9575

89. Jia H, Yang Q, Wang T, Cao Y, Jiang QY, Ma HD, Sun HW, Hou MX, Yang YP, Feng F. Rhamnetin induces sensitization of hepatocellular carcinoma cells to a small molecular kinase inhibitor or chemotherapeutic agents. Biochim Biophys Acta 2016;1860(7):1417-30. doi: 10.1016/j.bbagen.2016.04.007

90. Du FJ, Feng YX, Fang JZ, Yang MW. MicroRNA-143 enhances chemosensitivity of Quercetin through autophagy inhibition via target GABARAPL1 in gastric cancer cells. Biomed Pharmacother 2015;74:169-77. doi: 10.1016/j.biopha.2015.08.005

91. Shin VY, Chu KM. MiRNA as potential biomarkers and therapeutic targets for gastric cancer. World J Gastroenterol 2014;20(30):104329. doi: 10.3748/wjg.v20.i30.10432.

92. Feng $\mathrm{YH}$, Tsao $\mathrm{CJ}$. Emerging role of microRNA-21 in cancer. Biomed Rep 2016;5(4):395-402. doi: 10.3892/br.2016.747

93. Wang X, Cao L, Wang Y, Wang X, Liu N, You Y. Regulation of let-7 and its target oncogenes (Review). Oncol Lett 2012;3(5):955-60. doi: 10.3892/ol.2012.609 